\title{
Noradrenaline and Acidic Protein(s) in Four Types of Cat Carotid Body Chief Cells*
}

\author{
Peter Böck \\ Department of Anatomy (Prof. F. Hammersen), Technical University Munich, Munich, Federal \\ Republic of Germany
}

Received June 12, 1979

\begin{abstract}
Summary. Four types of chief cells can be discerned in the cat carotid body. These cells are referred to as types 1 to 4 . They are characterized-in the given order-by decreasing amounts of noradrenaline (argentaffin reaction) and acidic protein(s) (HCl hydrolysis/basic dye methods). The concentrations of acidic protein roughly parallel that of noradrenaline, being highest in type 1 cells and lowest in type 4 cells.

It is suggested that acidic protein and monoamines together are stored in specific granules and secreted by ekcytosis. The various cell types reflect functional conditions. Histochemical methods to identify acidic protein are less sensitive than methods for monoamines. Thus, only catecholamines have been detected in chief cells of those animals, which contain only a few and small specific granules. Cat carotid body chief cells, by contrast, serve as a suitable model to demonstrate the parallelism in storage and secretion of monoamines and acidic protein.
\end{abstract}

Carotid body chief cells (type I-cells) - as all paraganglionic cells-are members of the APUD cell series (PEARSE, 1969), and are also classified as paraneurons (FUJITA, 1976; for a review on this topic see KoBayAshi, 1976). Both of these cell families are assumed to be of neuroectodermal origin. They are believed to synthesize, to store, and to secrete peptide hormones as well as monoamines. At the fine structural level these cells are characterized by numerous electron dense "specific" granules.

Considering the well known chemical composition of adrenal chromaffin granules (WInkler and HörTnagl, 1973; WinkLer, 1976), and the close embryologic and morphologic relationship between carotid body chief cells and adrenal chromaffin cells, it seems likely to assume that specific granules of carotid body chief cells are composed of: 1) the limiting membrane; 2) carrier protein(s), probably of compound nature, e.g., glycoprotein(s); 3) enzyme(s); 4) peptide hormone(s) and/or prohormone(s); 5) monoamines; 6) ATP; and 7) divalent cations. This view is in full correspondence with FujiTA's concept of paraneurons (1976).

Morphologists primarily have drawn attention to monoamines of carotid body chief cells (Böck and Gorgas, 1976). The incorporation of tritiated leucine, dopa, dopamine, and ATP was studied only recently (КовауASHI, 1976). The present

\footnotetext{
* This work was supported by the "Deutsche Forschungsgemeinschaft," grant Nr. Bo 525/3.
} 
paper reports on attempts to demonstrate the proteins of specific granules in cat carotid body chief cells. Cats were chosen as experimental animals, because in this species more and larger specific granules are to be expected than in chief cells of other laboratory animals, e.g. in mice or rats.

Four types of chief cells can be discerned in the cat carotid body by means of the argentaffin reaction (MoriTA et al., 1969; Böck and GoRGAs, 1976). It was the aim of this study to test whether these cell types can be identified also by staining methods which are believed to demonstrate proteins of endocrine cells (lead-hematoxylin staining, demonstration of masked metachromasia).

\section{MATERIAL AND METHODS}

Carotid bodies of five female cats were used in this study. The animals were anesthetized with sodium pentobarbital, the carotid bifurcation was prepared and the carotid body removed together with the branching carotid artery. Tissues were fixed in picric-glutaraldehyde (saturated aqueous picric acid, 3 parts, 25\% glutaraldehyde, 1 part; in 1\% aqueous sodium acetate; Solcia and SAmpietro, 1968). Fixed specimens were dehydrated, embedded in Paraplast ${ }^{\circledR}$ and serially cut at $8 \mu \mathrm{m}$. Besides routine staining methods the following procedures were employed:

1. Argentaffin reaction in untreated sections (SINGH, 1964)

2. HCl-hydrolysis $\left(0.1 \mathrm{~N} \mathrm{HCl}\right.$ at $\left.60^{\circ} \mathrm{C}, 4 \mathrm{hrs}\right)$, followed by the argentaffin reaction (1)

3. HCl-basic dye staining (Solcia et al., 1968). Acid hydrolysis as in (2), followed by staining with $0.1 \%$ thionine (Merck, Darmstadt) in $0.1 \mathrm{M}$ acetate buffer, $\mathrm{pH} 5,30$ min at room temperature. The sections were washed in acetate buffer and studied in this aqueous medium

4. Sections stained with the HCl-basic dye method (3) were, after observation, subjected to the argentaffin method (1)

5. HCl-basic dye staining (3), using a $0.5 \%$ solution of alcian blue $8 \mathrm{GX}$ (Serva, Heidelberg) in $0.1 \mathrm{M}$ acetate buffer, $\mathrm{pH} 5,30 \mathrm{~min}$ at room temperature. The sections were washed in acetate buffer, dehydrated and mounted with DePeX ${ }^{\circledR}$

6. Staining with lead-hematoxylin (Solcia et al., 1969) after HCl-hydrolysis (2)

7. HCl-hydrolysis (2) followed by the argentaffin reaction (1) and finally by leadhematoxylin staining (6)

8. HCl-hydrolysis (2), followed by a short staining of nuclei with hematoxylin, thereafter staining with $0.01 \%$ Coriphosphine 0 (Chroma, Stuttgart) in $0.1 \mathrm{M}$ acetate buffer, pH 5 (Bussol ATI et al., 1969) to demonstrate fluorescence metachromasia of APUD cells. A Leitz fluorescence microscope with epiillumination system was used.

Counting of cell types was done in random fields, using an oil immersion objective $\times 100$. Values were expressed as $\% \pm M D$ and the significance of differences $(t$-test) was indicated.

\section{RESULTS}

\section{Argentaffin reaction}

Cell classification and counting was done in sections incubated for about $1 \mathrm{hr}$ at 

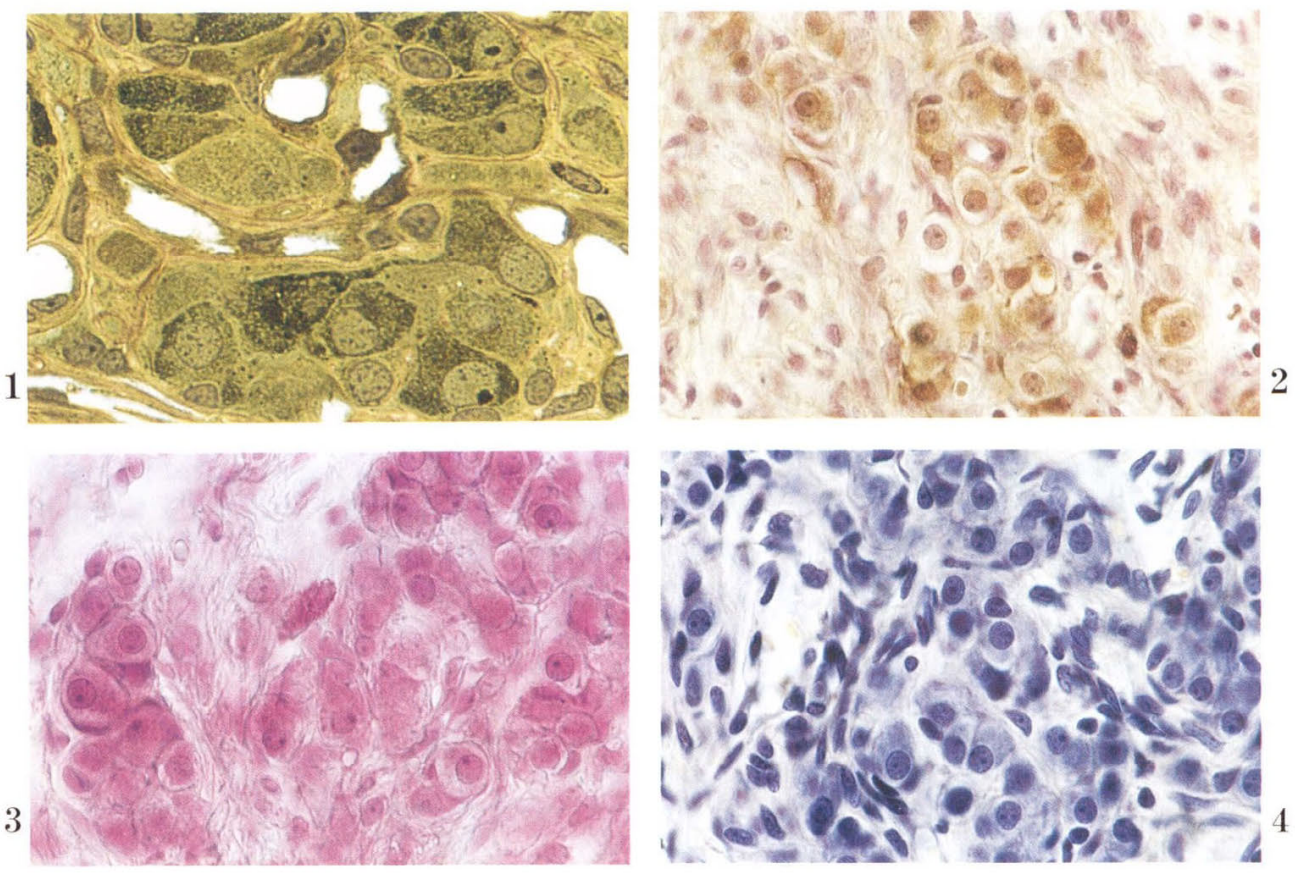

Fig. 1-4. Cat carotid body tissue, various preparation methods.

Fig. 1. Perfusion fixation with glutaraldehyde, postfixation with osmium tetroxide, semithin section. Staining with azure A followed by the argentaffin reaction. Chief cells contain varying amounts of argentaffin granules. Some chief cells form far reaching cytoplasmic processes. $\times 800$

Fig. 2. Immersion fixation in glutaraldehyde-picric acid (GPA) mixture, paraffin section. HClhydrolysis followed by staining with thionine ( $\mathrm{pH} 5$ ) and the argentaffin reaction. Chief cells display varying degrees of argentaffinity. $\times 400$

Fig. 3. Paraffin section of GPA-fixed material. HCl-hydrolysis followed by staining with thionine ( $\mathrm{pH} 5)$, mounted in acetate buffer $\mathrm{pH}=5$. Chief cells are seen to contain metachromatically stained material of pink to violet color. $\times 400$

Fig. 4. Paraffin section of GPA-fixed material. HCl-hydrolysis and staining with lead-hematoxylin. It is not possible to identify cell types on account of different staining intensity of encountered material. $\times 400$

$40^{\circ} \mathrm{C}$ in Singh's ammoniacal silver solution. The development of the argentaffin reaction was continuously controlled and stopped as soon as nuclei acquired a brownish shade. Only cells with nuclear profiles were counted.

Four types of chief cells can be discerned after applying the argentaffin reaction. These cell types will be referred to as type 1-type 4. Their morphological characteristics can be summarized as followes:

Type 1 appears black at lower magnifications. Numerous black granules, 1-2 $\mu \mathrm{m}$ in diameter, are seen within the cytoplasm of these cells at higher magnification. Type 1 cells are often ramified. They protrude long cytoplasmic processes which reach the surfaces of other chief cells (Fig. 1), forming there bouton-like terminals. Positively reacting cytoplasmic granules of type 1 cells facilitate the identification of cell processes even far away from the perinuclear region. 
Type 2 appears brown at lower magnifications; high magnification reveals clusters of brown granules in the perinuclear region. These clusters occupy oval or demilunar areas near the nucleus. The remaining cytoplasm stains homogeneously brown. The granules of type 2 cells are not markedly different in size from those of type 1 cells. Type 2 cells are ovoid or spherical, they do not form cytoplasmic processes. However, possibly existing cytoplasmic processes of type 2 cells easily may be overlooked when containing only few specific granules.

Type 3 displays no significant morphological differences from type II cells besides a less intensive argentaffin reaction. Type 3 cells appear yellow earth or brownish. There is no criterion for a clear distinction between strongly reactive type 3 cells and faintly staining type 2 cells.

Type 4 remains completely unreactive. These cells display a clear and homogeneous cytoplasm. Type 4 cells are of round or oval shape. They are found as single cells, being surrounded by other chief cells of any type.

Reproducible results could be obtained when counting the individual chief cell populations, though their distinction is only a subjective one. Percentages are shown in Table 1.

Table 1. Comparison of cell types in cat carotid body as revealed by the argentaffin reaction; untreated sections and after $\mathrm{HCl}$-hydrolysis ${ }^{1)}$

\begin{tabular}{cccccc}
\hline Method & Type 1 & Type 2 & Type 3 & Type 4 & $\mathrm{n}$ \\
\hline Argentaffin reaction & $5.10 \pm 1.58$ & $19.54 \pm 1.66$ & $72.53 \pm 3.01$ & $3.04 \pm 0.52$ & 1,113 \\
\hline $\begin{array}{l}\text { HCl-hydrolysis, argent- } \\
\text { affin reaction }\end{array}$ & $1.56 \pm 0.89^{* *}$ & $19.73 \pm 5.37$ & $77.31 \pm 5.59^{*}$ & $1.39 \pm 0.83^{* *}$ & 1,223 \\
\hline
\end{tabular}

1) Cell types as described in the text, values in $\% \pm \mathrm{MD}$

$* \mathrm{p}<0.05$

$* * \mathrm{p}<0.0005, \nu=17$

Cell typing in untreated sections was compared with results after hydrolyzing sections with $0.1 \mathrm{~N} \mathrm{HCl}$ for $4 \mathrm{hrs}$ at $60^{\circ} \mathrm{C}$. Under these conditions also four types of chief cells could be discerned. However, the argentaffin reaction was generally less intensive. Acid hydrolysis causes a significant numerical decrease of strongly reacting cells (type 1 ) in favor of increasing percentages of less reactive ones. Consequently the number of cells which are classified as type 3 increases.

Significant differences between untreated and HCl-hydrolysed sections were evaluated with exception of type 2 cells. However, in broad outlines the cell populations remained constant (Table 1 ).

\section{HCl-basic dye staining $(\mathrm{pH}=5)$}

Staining with thionine in acetate buffer, $\mathrm{pH}=5$, reveals metachromatically reacting granules in the cytoplasm of carotid body chief cells. There are a few cells which are tightly packed with violet granules. Cells with red cytoplasmic granules are much more numerous, while most chief cells display a faint pink color (Fig. 3). A few cells appear completely unstained. These four groups of chief cells are referred to as type 1 to type 4, respectively. Their frequency is shown in Table 2. 
Table 2. Comparison of cell types in cat carotid body as revealed by the HCl-basic dye staining method and by $\mathrm{HCl}$-argentaffin reaction in identical sections ${ }^{1)}$

\begin{tabular}{lccccc}
\hline \multicolumn{1}{c}{ Method } & Type 1 & Type 2 & Type 3 & Type 4 & $\mathrm{n}$ \\
\hline $\begin{array}{l}\text { HCl-hydrolysis } \\
\text { thionine, pH }=5\end{array}$ & $3.35 \pm 2.25$ & $29.72 \pm 5.63$ & $64.99 \pm 6.53$ & $2.44 \pm 2.89$ & 2.798 \\
\hline $\begin{array}{l}\text { HCl-hydrolysis thionine, } \\
\mathrm{pH}=5 \text {, argentaffin reac- } \\
\text { tion }\end{array}$ & $1.29 \pm 0.89^{*}$ & $22.11 \pm 4.33^{*}$ & $75.68 \pm 5.24^{* *}$ & $0.92 \pm 0.47$ & 2,612 \\
$\begin{array}{l}\text { 1) Cell types as described in the text, values in \% } \% \text { MD } \\
* \mathrm{p}<0.05\end{array}$ \\
$* * \mathrm{p}<0.001, \nu=17$ (one section was lost during the second staining reaction)
\end{tabular}

The cytoplasm of chief cells remains unstained when using the $\mathrm{pH} 5$ thionine solution for untreated sections. Hydrolysis with $0.1 \mathrm{~N} \mathrm{HCl}$ at $60^{\circ} \mathrm{C}$ for $4 \mathrm{hrs}$ was found most effective to reveal masked metachromasia of chief cell cytoplasmic granules. Longer incubation time or higher concentration of $\mathrm{HCl}$ causes loss of nuclear staining and extraction of cytoplasmic metachromatic material. Thus, two sources of error have to be considered: subjective cell classification and the methodology of acid hydrolysis.

The argentaffin reaction can be performed with sections already stained with the HCl-thionine method. Only faint blue staining of nuclei persists (Fig. 2). Argentaffin structures now appear gray to black, while a brownish shade is obtained in unstained sections. The percentages of the various cell types as defined in section 1 are given in Table 2. Results obtained by the HCl-basic dye/argentaffin reaction sequence significantly differ from those after HCl-basic dye staining. Comparison of Tables 1 and 2 makes clear that staining with thiazine dyes does not influence the argentaffin reaction.

Results with the $\mathrm{HCl}$-thionine method differ from those obtained by applying the argentaffin reaction to untreated sections (see Table 3), though the rough numerical relations between the individual cell types are easily recognized again.

Table 3. Comparison of cell types in cat carotid body as revealed by the argentaffin reaction, by $\mathrm{HCl}$-thionine, and by $\mathrm{HCl}$-alcian blue ${ }^{1)}$, 2)

\begin{tabular}{|c|c|c|c|c|c|}
\hline Method & Type 1 & Type 2 & Type 3 & Type 4 & $\mathrm{n}$ \\
\hline Argentaffin reaction & 5. $10 \pm 1.58$ & 19. $54 \pm 1.66^{*}$ & $72.53 \pm 3.01^{*}$ & 3. $04 \pm 0.52$ & 1,113 \\
\hline $\begin{array}{l}\text { HCl-hydrolysis, } \\
\text { thionine, } \mathrm{pH}=5^{22}\end{array}$ & 3. $35 \pm 2.25$ & 29. $72 \pm 5.63$ & $64.99 \pm 6.53$ & 2. $44 \pm 2.89$ & 2,798 \\
\hline $\begin{array}{l}\mathrm{HCl} \text {-hydrolysis, } \\
\text { argentaffin reaction }\end{array}$ & $2.05 \pm 0.75$ & 15. $46 \pm 4.56^{* *}$ & $80.25 \pm 5.47^{* *}$ & $2.25 \pm 0.61$ & 1,223 \\
\hline $\begin{array}{l}\mathrm{HCl} \text {-hydrolysis, alcian } \\
\text { blue } 8 \mathrm{GX}, \mathrm{pH}=5\end{array}$ & $0.24 \pm 0.34$ & 19. $07 \pm 5.08$ & $80.70 \pm 4.98$ & - & 1,009 \\
\hline
\end{tabular}


Staining with alcian blue at pH 5 after HCl-hydrolysis yields similar results as the HCl-argentaffin reaction method. Type 4 cells, i.e., cells with completely unreactive cytoplasm, were not observed. Detailed percentages are given in Table 3.

\section{Lead-hematoxylin staining}

Lead-hematoxylin after $\mathrm{HCl}$-hydrolysis stains the cytoplasm of carotid body chief cells. As to the staining intensity, no classification of cell types was possible (Fig. 4). Combination of the argentaffin reaction with lead-hematoxylin stainig shows that those cytoplasmic regions are stained by the dye lake, which also reduces ammoniacal silver solutions. Thus, lead-hematoxylin stains argentaffin granules or argentaffin cytoplasmic regions but the varying intensity of the argentaffin reaction is not paralleled by varying dye intensity.

\section{Staining with Coriphosphine 0}

No fluorescence metachromasia could be observed in sections stained with Coriphosphine $\mathrm{O}$ after acid hydrolysis. Most probably this is due to insufficient quality of the dye, because other methods to demonstrate negatively charged groups were successfully used.

\section{DISCUSSION}

1. Terminology and classification of chief cells on account of stored monoamines

Carotid body parenchyma is composed of chief cells (also called main cells, specific cells, glomus cells, chemoreceptor cells, type I-cells). The chief cell is the chromaffin cell, the paraganglionic cell, the APUD cell, the paraneuron. Sustentacular cells structurally and functionally correspond to Schwann cells. The terms type I-cells and type II-cells widely have been used as synonyms for chief cells and sustentacular cells. The terms type I to type IV were also used to designate various forms of chief cells (MoRita et al., 1969) and this terminology has been adopted later on (Böck and Gorgas, 1976). To avoid any confusion, the various forms of chief cells are indicated in this paper with corresponding arabicals. Thus, the numbers may be used even in combination without confusion, e.g. type $\mathrm{I} / 3$ means a chief cell of the third type.

Various types of chief cells have been defined, considering the nature of the stored biogenic amine(s) and its(their) amount(s). Noradrenaline is quantitatively

Table 4. Cell types of cat carotid body chief cells as identified by means of the argentaffin reaction

\begin{tabular}{clr|cc}
\hline & \multicolumn{2}{c|}{ This paper } & \multicolumn{2}{c}{ MoR ITA et al., } \\
\hline Called & Argentaffin reaction & $\%$ & Frequency & Called \\
\hline Type 1 & Black granules & 5 & Rare & I \\
Type 2 & Brown granules & 20 & Occasionally & III \\
Type 3 & Brownish, yellow earth & 72 & Most frequently & II \\
Type 4 & Unreactive & 3 & Difficult to find & IV \\
\hline
\end{tabular}


precipitated during tissue fixation with glutaraldehyde (Hopwood, 1971). The resulting reaction product reduces ammoniacal silver solutions, even after postfixation with osmium tetroxide. Dopamine, on the other hand, is not precipitated by fixation with glutaraldehyde and therefore no argentaffin reaction is to be expected. This methodology has been used at the fine structural level (MoRita et al., 1969) and for combined light and electron microscopy (BöcK and GoRGAS, 1976), and served also as the basis for this study. Glutaraldehyde picric acid (GPA) fixation was sufficient to identify four types of chief cells, termed type 1 to 4 in relation to their decreasing argentaffinity. Their frequency constantly was found as follows: the sum of type 1 and type 4 accounts for less than $10 \%$ of carotid body chief cells. One quarter of the remaining $90 \%$ is contributed by type 2 , the rest by type 3 (cf. Table 1 ). These percentages were regularly found, though the various countings reported in this paper often differ significantly. However, this may bear no consequences because of the inexact criteria to discriminate between the various forms of chief cells.

Results of the present study can be compared with those of Morita et al. (1969) and Böck and Gorgas (1976) on the basis of identical methodology, though they have been obtained at different levels of microscopical solution. To give a survey and to clarify terminology, these findings are composed in Table 4.

\section{Classification of chief cells on account of stored proteins and its correlation with the monoamine content}

Staining with basic dyes at pH 5 after acid hydrolysis shows varying amounts of negatively charged proteins in carotid body chief cells. Four types of chief cells can be discerned in relation to decreasing amounts of polyanions. When comparing the percentages of these cell populations, three main sources of errors must be considered: 1 ) the meager morphological criteria to discriminate the cell types, 2) the methodological influences on demonstrating masked metachromasia, i.e., temperature, time, and $\mathrm{HCl}$-concentration during the hydrolysis step, and 3) the effect of $\mathrm{HCl}$-hydrolysis on the argentaffin reaction, that serves as "standard."

As shown in Tables 2 and 3, the percentages of the four types of chief cells significantly differ when being revealed by different methods. However, a rough outline of proportions remains to be recognized (vide supra).

$\mathrm{HCl}$-basic dye methods demonstrate terminal and side-chain carboxyls. Metachromatic staining is an indicator for tight packing of dye molecules and therefore for tight assembly of tissue polyanions. Feulgen-type hydrolysis removes RNA and part of DNA, thus unmasking the staining reaction of underlying polycarboxyl-

\begin{tabular}{lc|l}
\hline 1969 & & \multicolumn{1}{c}{ BöcK and GorGas, 1976 } \\
\hline Argentaffin reaction & Mean granule $\varnothing, \mathrm{nm}$ & \multicolumn{1}{c}{ Stored monoamine } \\
\hline Quickly developed & $170-400$ & Noradrenaline \\
+ & 93 & Preferentially noradrenaline, some dopamine \\
Slowly developed & 130 & Preferentially dopamine, some noradrenaline \\
No reaction & 120 & No noradrenaline \\
\hline
\end{tabular}


groups. Additionally, mineral acid hydrolysis cleaves carboxamido groups and also breaks intra- and interchain linkages of the protein coils, producing new carboxyl groups (Bussolati et al., 1969). The metachromatic staining reaction is less advantageous to estimate the quantity of tissue polyanions. Metachromasia means both a shift of absorption maximum to shorter wavelength and concomitantly a decrease of absorption intensity (SCHEIBE and ZANKER, 1958). Metachromatically staining dyes do not follow BEER's law. Thus staining with the non-metachromtic dye alcian blue renders more reliable data as to the amount of negative charges.

Results of HCl-basic dye staining fit well with determinations of amino acids and other ninhydrine-positive substances in cattle carotid bodies (HARMs, 1979). A surprisingly high amount of taurine seems to be characteristic for carotid body tissue (which contrasts to observations in the superior cervical ganglion), as well as high amounts of glutamic acid (cf. Table 5). On the other hand, only traces of tryptophane were found in bovine carotid body, which amino acid recently has been suggested to be present in human paraganglionic cells as constituent of a hypothetic peptide hormone (Hervonen et al., $1978 \mathrm{a}, \mathrm{b}$ ). Furthermore, the small amounts of the otherwise widely distributed amino acid leucine indicate this substance as inade-

Table 5. Amino acids and taurine in bovine carotid body, superior cervical ganglion, and adrenal medulla (Residues/1000). From: Harms, 1979

\begin{tabular}{|c|c|c|c|}
\hline & $\begin{array}{l}\text { Carotid body } \\
n=5\end{array}$ & $\begin{array}{l}\text { Cervical ganglion } \\
\qquad \mathrm{n}=4\end{array}$ & $\underset{n=1}{\text { Adrenal medulla }}$ \\
\hline Hydroxyproline & n. c. & 14 & 2 \\
\hline Aspartic acid & 81 & 99 & 75 \\
\hline Threonine & 17 & 31 & 24 \\
\hline Serine & 33 & 62 & 30 \\
\hline Glutamic acid & 263 & 293 & 284 \\
\hline Proline & 17 & 19 & 12 \\
\hline Glycine & 116 & 118 & 119 \\
\hline Alanine & 80 & 112 & 91 \\
\hline Cystine/2 & n. c. & n. c. & n. c. \\
\hline Valine & 21 & 25 & 14 \\
\hline Methionine & 4 & 4 & 4 \\
\hline Isoleucine & 9 & 7 & 10 \\
\hline Leucine & 16 & 14 & 17 \\
\hline Tyrosine & 6 & 7 & 4 \\
\hline Phenylalanine & 6 & 5 & 5 \\
\hline Lysine & 7 & 8 & 2 \\
\hline Histidine & 10 & 7 & 5 \\
\hline Tryptophane & 1 & 1 & 2 \\
\hline Arginine & 10 & 11 & 16 \\
\hline Glutamine + Asparagine & 65 & 125 & 39 \\
\hline Taurine & 238 & 37 & 244 \\
\hline $\begin{array}{l}\text { Taurine+ Glutamic } \\
\text { acid + Aspartic acid }\end{array}$ & 582 & 375 & 603 \\
\hline
\end{tabular}


quate to study the incorporation of tritiated compounds into newly synthasized protein (Kobayashi, 1976). Table 5 also shows the close relationship between carotid body tissue and adrenomedullary tissue concerning their amino acid composition. This lends support to the assumption that acidic proteins are main constituents of specific granules in both organs. The limiting fact for histochemical staining of these proteins is their relative scarcity in the carotid body when compared to their concentration in adrenomedullary cells. Basic dye methods, therefore, do not yield significant staining of carotid body chief cells in those animals which display only few and small specific granules, e.g., mouse and rat (Вöск, 1979). Accordingly, human carotid body chief cells are stained (CAPELla and Solcia, 1971) as well as those of the cat (this paper), both of which are known to contain large quantities of specific granules (Böck et al., 1970, Morita et al., 1969).

Staining with thiazine dyes or with alcian blue is abolished after methylation of the sections. This is not the case with lead-hematoxylin, where part of the dyebinding capacity of the substrate remains unblocked (Solcia et al., 1969). Thus, additional mechanism(s) of dye binding must be considered. These as yet unkown mechanisms could be responsible for the different results observed after staining with lead-hematoxylin as compared to other basic dyes. Results obtained with leadhematoxylin did not allow to discern various cell types but rather show uniform populations of chief cells. As to the intensity of lead-hematoxylin staining it should be emphasized that carotid body chief cells in the cat are much less intensively colored than other positively reacting paraneurons, e.g., thyroid C cells (KAMEDA, 1976). While there was a rough correlation between argentaffin reaction (i.e., noradrenaline content) of the various cell types and their staining with $\mathrm{HCl}$-basic dye methods, this is not the case with lead-hematoxylin. Similar observations were made in the rat, mouse, and guinea pig, where no correlation could be found between lead hematoxylin staining and catecholamine fluorescence (Böck and GoRGAS, 1978).

\section{Conclusions}

Chemical determinations of monoamines in the cat carotid body revealed significant amounts of noradrenaline and dopamine, with a molar ratio of about 1:2.3 (CHIOccio et al. 1971, a, b; ZAPATA et al., 1969). Histochemical results indicate that no distinct cell groups exist which exclusively store either of these substances. More probably dopamine and noradrenaline are present in any chief cell in varying amounts. Noradrenaline, which can be demonstrated by means of the argentaffin reaction when exceeding a certain concentration, serves as a parameter to discriminate cell types. There is no proof that the sum of noradrenaline plus dopamine is constant per chief cell, though one is inclined to suppose this (see Table 4). Theoretically all dopamine could be stored in type 4 cells, while type 1 to 3 cells store varying amounts of noradrenaline. However, the small number of type 4 cells (3\%) and the vast amount of dopamine makes this possibility unlikely. Fluorescence histochemical studies also brought evidence in this direction (CHIoccio et al., $1971 \mathrm{a}, \mathrm{b}$ ). In rats, where similar relations between noradrenaline and dopamine have been measured (HELLSTRöm and KosLow, 1975), the light microscopical identification of noradrenaline storing cells is not possible: noradrenaline concentrations are too low to yield an argentaffin reaction $(35 \mu \mathrm{g} \mathrm{NA} / \mathrm{g}$ in the rat carotid body versus $196 \mu \mathrm{g} \mathrm{NA} / \mathrm{g}$ in the cat carotid body; Hellström and Koslow, 1975; Zapata et al., 1969). 
The amount of negatively charged protein(s) roughly parallels the amount of noradrenaline per chief cell. It may be argued that HCl-basic dye staining is significant for postulated peptide hormone(s) and/or their precursor(s) (SolciA et al., 1969). When assuming the carotid body as endocrine gland (as it is done by the APUDand paraneuron-concept) it seems likely that the individual gland cells continuously synthesize and secrete their specific products. Cells which store significantly more or less protein than others should be a minority. Varying amounts of protein would indicate functional conditions of endocrine cells. It becomes evident that any classification of cell types on behalf of encountered acidic protein must be an arbitrary one. Classification of chief cells is unnecessary because it permits no better understanding of the organ. It was done in this study to show that less than $10 \%$ of carotid body chief cells are either devoid of acidic proteins (most probably after having secreted them) or crowded with these substances (most probably after having not been stimulated for a long time). Assuming that noradrenaline, together with acidic protein(s), is synthesized and stored within specific granules of chief cells and secretion of specific granules means ekcytosis of their entire content, the above correlation appears as a consequence. Most probably the same is true for dopamine, but this compound yields no argentaffin reaction. Combined fluorescence histochemistry and lead-hematoxylin staining (Böck and GoRGAs, 1978) revealed no correlation between amines and lead-hematoxylin positive substances in individual chief cells (mouse, rat, guinea pig). However, as already mentioned, the mechanism of lead hematoxylin staining is not completely clear, and lead hematoxylin was used in the quoted study without prior hydrolysis of the sections: thus the results are obscured by additional staining of ribonucleoproteins.

Acidic secretory protein(s) in cat carotid body chief cells has been demonstrated roughly to correlate with the amount of stored noradrenaline. It seems likely that also chief cells of other laboratory animals, such as rat or mouse, store similar protein(s) but the histochemical methods are not sensitive enough for their detection.

The sensitivity of fluorescence methods revealed dopamine and noradrenaline also in chief cells of those species, where acidic proteins are too few in amount to be demonstrated. Thus, catecholamines have captured all the attention which essentially is due to protein(s), the sources of probably existing peptide hormone(s). Amine handling may be a secondary functional capacity of carotid body chief cells (as it is a secondary phenomenon in thyroid $\mathrm{C}$ cells or in pancreatic islets) which recalls to us the ontogeny of these cells. Monoamines are excellent parameters to indicate the functional activity of chief cells, being concentrated even in cells of low activity (BöcK and GoRGAs, 1978). Obviously secreted monoamines retain their biological afficacy, by possibly acting on the chief cell itself (inhibiting or stimulating further secretion), or on various types of synaptic connections of chief cells, or by influencing possibly existing receptor terminals, or other structures near the glomus parenchyma. 


\section{REFERENCES}

Böck, P.: Staining of paraganglionic cells with lead-haematoxylin. Z. mikr.-anat. Forsch. (in press).

Böck, P. and K. Gorgas : Catecholamines and granule content of carotid body type I-cells. In: (ed. by) R. E. Coupland and T. Fujita: Chromaffin, enterochromaffin and related cells. Elsevier, Amsterdam, 1976 (p. 355-374).

- Catecholamine fluorescence and staining with lead-hematoxylin of the carotid body type I-cells. In: (ed. by) R. E. Coupland and W. G. Forssmann: Peripheral neuroendocrine interaction. Springer Verlag, Berlin-Heidelberg, 1978 (p. 106-111).

Böck, P., L. Stockinger and E. Vyslonzil : Die Feinstruktur des Glomus caroticum beim Menschen. Z. Zellforsch. 105: 543-568 (1970).

Bussolati, G., F. W. D. Rost and A. G. E. Pearse: Fluorescence metachromasia in polypeptide hormone-producing cells of the APUD series, and its significance in relation to the structure of the precursor protein. Histochem. J. 1: 517-530 (1969).

Capella, C. and E. Solcia: Optical and electron microscopical study of cytoplasmic granules in human carotid body, carotid body tumours and glomus jugulare tumours. Virchows Arch. B7: $37-53$ (1971).

Chiocchio, S. R., M. P. King and E. T. Angelakos: Carotid body catecholamines. Histochemical studies on the effect of drug treatments. Histochemie 25: 52-59 (1971a).

Chiocchio, S. R., M. P. King, L. Carballo and E. T. Angelakos: Monoamines in the carotid body cells of the cat. J. Histochem. Cytochem. 19: 621-626 (1971b).

Fujita, T.: Gastro-enteric endocrine cell and its paraneuronic nature. In: (ed. by) R. E. Coupland and T. Fujita: Chromaffin, enterochromaffin and related cells. Elsevier, Amsterdam, 1976 (p. 191-208).

Harms, B.: Gehalte an freien Aminosäuren, biogenen Aminen und Neurotransmittern und Untersuchungen zur Catecholamin-Biosynthese im Glomus caroticum des Rindes. Doctoral Thesis, University of Hamburg, 1979.

Hellström, S. and S. H. Koslow : Biogenic amines in carotid body of adult and infant rats-a gas chromatographic-mass spectrometric assay. Acta physiol. scand. 93: 540-547 (1975).

Hervonen, A., S. Partanen, A. Vaalasti, M. Partanen, L. Kanerva and H. Alho: The distribution and endocrine nature of the abdominal paraganglia of adult man. Amer. J. Anat. 153: 563-572 (1978a).

Hervonen, A., A. Vaalasti, S. Partanen and L. Kanerva: Endocrine nature of paraganglia of man. Experientia (Basel) 34: 111-112 (1978b).

Hopwood, D.: The histochemistry and electron histochemistry of chromaffin tissue. Progr. Histochem. Cytochem. 3: 1-66 (1971).

Kameda, Y.: Fine structural and endocrinological aspects of thyroid parafollicular cells. In: (ed. by) R. E. Coupland and T. Fujita: Chromaffin, enterochromaffin and related cells. Elsevier, Amsterdam, 1976 (p. 155-170).

Kobayashi, S.: An autoradiographic study of the mouse carotid body using tritiated leucine, dopa, dopamine and ATP with special reference to the chief cell as a paraneuron. Arch. histol. jap. 39: 295-317 (1976).

Morita, E., S. R. Chioccio and J. H. Tramezzani : Four types of main cells in the carotid body of the cat. J. Ultrastr. Res. 28: 399-410 (1969).

Pearse, A. G. E.: The cytochemistry and ultrastructure of polypeptide hormone producing cells of the APUD series and the embryologic, physiologic and pathologic implications of the concept. J. Histochem. Cytochem. 17: 303-313 (1969).

Scheibe, G. and V. Zanker: Physikochemische Grundlagen der Metachromasie. Acta histochem. 
(Jena) Suppl. 1: 6-35 (1958).

Singh, I.: A modification of the Masson-Hamperl method for staining of argentaffin cells. Anat. Anz. 115: 81-82 (1964).

Solcia, E., C. Capella and G. Vassallo: Lead-haematoxylin as a stain for endocrine cells. Significance of staining and comparison with other selective methods. Histochemie 20:116-126 (1968).

Solcia, E., G. Vassallo and C. Capella : Selectrive staining of endocrine cells by basic dyes after acid hydrolysis. Stain Technol. 43: 257-263 (1968).

Winkler, H.: The composition of adrenal chromaffin granules: An assessment of controversial results. Neuroscience 1: 65-80 (1976).

Winkler, H. and H. Hörtnagl : Composition and molecular organisation of chromaffin granules. In: (ed. by) E. Usdin and S. Snyder: Frontiers in catecholamine research. Pergamon, Oxford, 1973 (p. 415-421).

Zapata, P., A. Hess, B. L. Bliss and C. Eyzaguirre: Chemical, electron microscopic and physiological observations on the role of catecholamines in the carotid body. Brain Res. 14: 473496 (1969).

Prof. Dr. Peter Böck

Department of Anatomy

Technical University Munich

Biedersteinerstraße 29

D-8000 München 40

Federal Republic of Germany 